\title{
The Impact of Corporate Governance on the Insurance Firm's Performance in Bahrain
}

\author{
Naser Najjar \\ Faculty of Economic and Business, Jadara University, Irbid, Jordan \\ E-mail: najjarnaser@hotmail.com
}

Accepted: February 18, 2012 Published: March 17, 2012

Doi:10.5296/ijld.v2i2.1412 URL: http://dx.doi.org/10.5296/ijld.v2i2.1412

\begin{abstract}
The importance of responsibility, accountability, transparency and fairness are raising the issues of their effect on the performance of the firm and the managers as well. This is closely related to the agency problem because corporate governance mechanisms intend to induce managers to act according to the best interest of the shareholders, which is by maximizing the firm's value and ultimately reducing agency costs.

This study is a contribution to other studies conducted to examine the impact of corporate governance mechanisms on firm's performance of the insurance industry in Bahrain, understand how to minimize the agency costs effectively and design the appropriate organizational structure. Also, to distinguish between good and bad corporate governance which is a crucial step in building the market's confidence and attracting positive investment flows to the institution and the economy.

E-views program has been used to regress and the method the Pooled data. Five insurance companies listed in BSE have been selected as a sample for this study for the period of 2005-2010. Therefore, the total panel of observations is 30 .

The research concludes that there is no statistically significant impact of corporate governance expressed by CEO status, ownership concentration, the number of employees, industry performance, and number of shares traded on firm's performance in the insurance industry expressed by the dependent variable - return on equity (ROE). On the other hand board size, firm size, number of block-holders found to have statistically significant impact on firm's performance in the insurance industry expressed by the dependent variable - return on equity (ROE). This result, confirms the importance of good governance structure on the firm and the whole economy in the long run.

The researcher suggests that every insurance firm should properly define corporate governance and its mechanisms and implement them effectively in order to reach the firm's long-term goals, build stakeholders' confidence and generate positive investment flows.
\end{abstract}


The recent financial crisis has had enormous impacts on the economy, leading to major problems in insurance companies. Therefore, an insurance company should focus on good corporate governance that will build a stable foundation for recovering from this crisis.

Regarding future line of research, efforts should be put at increasing the sample size, the corporate governance variables, and the time frame in order to have more accurate and reliable results.

More importantly, the empirical literature indicates a sample selection bias in favor of very big firms. It is hereby suggested that attention should be devoted to the study of small- and medium-scale firms. This is because these firms account for at least $90 \%$ of the total number of firms in the world.

Keywords: Corporate governance, firm size, Firm performance, Ownership concentration, insurance sector

\section{1- Introduction}

What is corporate governance? What are its mechanisms? And how these mechanisms affect the firm's performance? A lot of research has been conducted to answer these questions and to define good corporate governance that sets the principles and guidelines on how to conduct, control and monitor a business. Most of these researches focused on the link between two governance mechanisms and one or two measurements of performance.

After the collapse of Enron and the corporate scandals that started in October 2001 till the present day the investor's confidence in the market has shaken and that's why many institutional investors, business publications, board of directors and government regulators have all encouraged firms to focus on corporate governance from different aspects including economics, finance, law, management and accounting.

Not to mention that countries and economies vary regarding to what governance mechanisms are used. For example, in Taiwan, family ownership is the most popular one, while in Angelo-American economy; the equity market is the primary mechanisms. Whether it's in Asia, Europe or USA, it is highly important to appropriately structure the organization and implement the right governance mechanisms that will help with the decision-making process. This paper studies the impact by examining several governance mechanisms and their effects on firm performance measured by return on equity (ROE). These mechanisms include: the size of the board, CEO status, ownership concentration, and firm size, number of employees, industry performance, blockholders, and finally number of shares traded. By comparing these factors, we conclude how important it is for a firm to have a mix of different governance mechanisms as they are interrelated to each other.

\subsection{Problem Statement}

This paper studies how corporate governance mechanisms impact the firm's performance. Because Bahrain offers great opportunities for investors, this makes it unique in the region and attractive for more investment flows. However, this increases the pressure on firms to develop corporate governance and provide higher protection for the stakeholders generally. 


\subsection{Purpose of the Study \& Objectives}

This study is a contribution to other studies conducted to examine the impact of corporate governance mechanisms on firm's performance, understand how to effectively minimize the agency costs and design the appropriate organizational structure. This research is conducted to distinguish between good and bad corporate governance which is a crucial step in building the market's confidence and attracting positive investment flows to the institution and the economy.

The research main objectives are to:

- Draw a line between good and bad corporate governance;

- Determine corporate governance mechanisms and their effect on firm's performance in the insurance sector;

- Raise the awareness about agency theory and its relative costs; and

- Observe the Bahraini economy generally and the insurance sector specifically.

\subsection{Significance of the Study}

Only few research have been conducted on the GCC-business environment and none on the Bahraini market specifically; hence this paper intends to increase the knowledge and awareness of how critical and crucial corporate governance is, especially after the financial crisis that led to a recession in the worldwide economy.

\section{Background}

\subsection{Bahrain's economy}

Because it is full of human capital and natural geographic advantages, along with a stable economic climate and business-friendly environment, Bahrain has proved to be the most attractive country for foreign and local investors in the region.

Since a very long time, Bahrain has had the freest economy in the Middle East and has improved its ranking internationally - according to the Index of Economic Freedom; Bahrain is ahead of G7 economies like Germany, France and Japan, as well as other major developing countries like China and India. Demonstrating the strength of the economic model, the sovereign credit ratings have remained strong. These ratings are: Standard \& Poor's, A/Stable/A-14; Fitch, A.5.

Investors in Bahrain can enjoy conducting business worldwide as it has economic agreements and bilateral trade with more than 40 countries, including China, France, India, Singapore and the UK. Since 2004, it has had an active Free Trade Agreement with the United States. Foreign investors can preserve $100 \%$ foreign ownership and take advantage from the region's lowest taxes, without any corporation, income, value-added or withholding tax. There are also no capital gains, wealth taxes, no inheritance taxes or death duties.

Bahrain's regulatory regime provides an open, free and transparent environment that fosters growth. Track record and global best-practice standards are established to protect companies' rights and strict intellectual property and copyright laws are enforced which ensure the highest standards of protection. This makes investors feel more secured by investing in transparent, safe and consistent market. 


\subsection{Insurance Sector in Bahrain}

Situated at the centre of one of the fastest-growing insurance markets worldwide, Bahrain is a hub for the insurance and re-insurance industry with a total of 150 insurance companies of all types - general, life, reinsurers, and captive insurers. These companies include both conventional and Islamic institutions, serving onshore and offshore markets.

Conventional insurers in Bahrain include: Zurich Insurance, AIG, Allianz Insurance, Al Ahlia Insurance Co., Royal \& Sun Alliance, and Arab Insurance Group. Islamic insurers include: Allianz Takaful, Takaful International Company, Bahrain Islamic Insurance Co., and Solidarity Takaful.

Insurance sector has grown steadily and strongly in recent years, especially after the downturn of the financial crisis in 2007. For example, in 2009, total gross premiums increased by $30 \%$ compared to the previous year. Long-term insurance (life and saving products) has driven the most of this expansion. The fire, engineering, medical and motor insurance sector have also grown significantly.

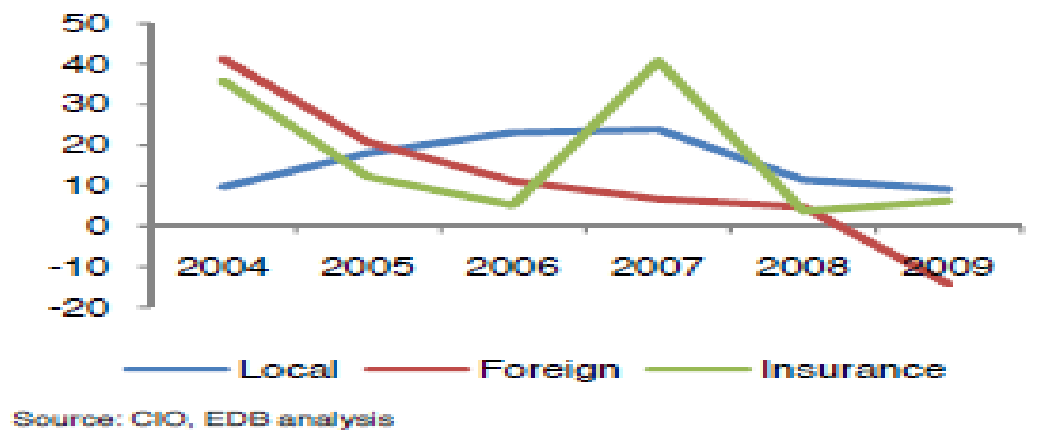

Figure

Growth of the Finance Sector

The Central Bank of Bahrain (CBB) supervises the insurance sector and it recently made it mandatory for all independent financial advisors to attain internationally recognised qualifications, and that's a first in the Middle East. All legal, regulatory and supervisory insurance frameworks are provided based on the essential criteria of the International Association of Insurance Supervisors' (IAIS) core of principles and methodology.

The Bahrain Insurance Association (BIA) received its charter in 1993 and currently it is incorporated officially under the CBB. It aims at promoting the insurance industry, setting ethical and professional insurance standards and facilitating the exchange of information and statistics among its 53 members. The Gulf Insurance Institute (GII), which specifically trains insurance professionals, opened its doors in Bahrain in 2008, providing the sector with highly trained insurance workforce.

\subsection{Literature Review}

The concept of insurance, according to (Gollier C., 2003), involves pooling funds from many insured entities (known as exposures) in order to pay for losses which can occur to these entities. The insured entities are therefore protected from risk for a fee - premium, with the fee being dependent upon the frequency and severity of the event occurring. In order to be 
insurable, the risk insured against must meet certain characteristics. Insurance is a commercial enterprise and a major part of the financial services industry, but individual entities can also self-insure through saving money for possible future losses.

The requirement to promote good corporate governance, both within and outside the financial services sector, is receiving increased international attention. The IAIS has therefore decided to produce a compilation of the Insurance Core Principle on Corporate Governance which outlines the standards and guidance notably related to various corporate governance aspects, to provide a comprehensive set of regulatory and supervisory best practice on this issue.

More importantly, it is proven that countries with good and reliable corporate governance tend to have developed markets where the economic growth can be stimulated, especially with those which rely heavily on external finance and have weak legal environment. So, we can conclude that corporate governance is not only important to the operating performance and firm's value, but also to the whole country at a macro level (Sapovadia, 2009).

As mentioned before, the financial scandals that hit the market in recent years, and the collapse of so many institutions such as Enron, WorldCom, Commerce Bank and XL Holidays, aligned with the recent financial crisis, forced the firms to concentrate more on good corporate governance and to develop and implement several effective mechanisms in order to have the investors' confidence and faith back again (Young, 2003).

According to the Insurance Regulatory and Development Authority in India (IRDA, 2009), the regulatory responsibility to protect the welfare of the policyholders demands that insurance firms have in place, good governance practices for the maintenance of sound long-term investment policies, solvency and underwriting risks on a prudential basis. Any governance principles adopted by the insurance industry should be flexible enough to take into account the variety of insurers within its purview, because obviously “one size doesn't fit all" and each insurance company tailors its corporate governance procedures according to its own circumstances.

An effective corporate governance framework will impose appropriate standards to recognise and protect the rights, relationships and interests of all interested parties in the insurance firm, named stakeholders. It also prevents the abuse of self-serving conduct along with the imprudent and high risk behaviour; therefore it resolves the conflict of interest between managers, board of directors, employees, shareholders and the policyholders (Tzafrir, 2005). Board of director is a focal point of the corporate governance system. It should ultimately be held accountable and responsible for the actions of the insurer and that's why the latter should be managed prudently. The board can be formed in different structures. However, companies are expected to have a significant number of independent directors who have no employment or other material business relationship in the company. This is mainly because director independence is believed to enhance the independent business judgment by boards for the benefit of the company's shareholders. This view has been supported in the work of (English, et al, 2005).

IAIS (2004) emphasized that directors, independent or not, in any insurance company should: 
- $\quad$ set out their responsibilities in accepting and following the regulations and principles of corporate governance and conduct an annual self assessment which intends in evaluating and addressing their weaknesses and strengths;

- Establish a charter to specify the code of business conduct and ethics and the means to attain them. This charter should deal with different aspects such as: transactions, relationships, risk management, fair self-dealing, minimum solvency, capital margin, required reserve requirement, confidentiality, compliance with laws, and internal control;

- $\quad$ supervise prudently the managers and executive officers to make sure that they adhere to the policies and strategies mentioned in the firm's charter;

- conduct regular meetings with the managers and executives to keep up with flow of business and be aware of the latest updates and problems;

- may establish special committees with specific responsibilities such as: compensation committee, audit committee and risk management committee; and

- Ensure fair treatment to all policyholders and employees and guarantee the sharing of information and disclosure between them in a transparent manner.

These responsibilities are not fixed, and may be changed from one insurance company to another.

Another corporate governance aspect concerns employees and managers (Tzafrir. 2005). Those should have a fine competence level for their roles, and should ascertain whether they have the appropriate ability and integrity to conduct insurance business. Their competence can be judged from the level of their professional and formal qualifications or the relevant practical experience in the insurance or financial industry. All insurers should conduct themselves in a fair and ethical manner in accordance to the code of business conduct and ethics established by the board of directors.

Insurance policies are legal contracts between an insurer and its policyholders. An insurer should not be able to alter the terms of a contract without notifying the policyholder. Moreover, the value and benefits of the existing policies should not be lessened or changed without the policyholder's approval.

According to a research conducted by (Mustafa, et al, 2009) internal control and auditing is a critical dimension of corporate governance. The oversight and reporting systems will allow the board and management to monitor whether the operations are conducted in accordance with the firm's policies or not. It also provides a foundation for the safety and soundness of the insurer and a systematic and disciplined approach for evaluating and improving the effectiveness of the work process and its compliance with the regulations.

Mustafa, et al (2009) also mentioned that every insurance company should maintain accurate and verifiable records of all the transactions made. These records include: a premiums register, a premiums ledger, premium reports, a claims register, claims reports, a general ledger, an income statement, and a balance sheet. Each insurance company should audit their accounts and the financial reports annually by their internal audit committee and an external legal audit firm. The audit firm should report directly to the CBB if any fraudulent actions are committed by the insurer. 
The board of directors should receive regular reporting on the effectiveness of the internal controls. Internal control deficiencies, either identified by management, staff, internal audit or other control personnel, are reported in a timely manner and addressed promptly. The internal audit committee should have access to all of the insurers' transactions and enough resources employ highly trained and experienced staffs use an effective methodology to assess the risk and be appropriately independent to conduct their tasks effectively.

In addition, Mustafa, et al (2009) emphasized that the corporate governance framework should ensure that timely and accurate disclosure is made on all material matters regarding the insurance corporation, including the financial situation, performance, ownership, and governance of the company, in order to give prospective and existing stakeholders a clear view of its business activities and financial position and to facilitate the understanding of the risks to which it is exposed.

Stakeholders generally and policyholders specifically have the right to deal with insurance companies that operate in a fair, efficient, and stable market. Transparency and public disclosure would provide the whole market with appropriate discipline and facilitate its smooth functioning that will reward those insurers who operate efficiently and effectively and penalise those who don't.

Information disclosed should be:

- Relevant to decisions taken by market participants;

- Up-to-date and available in a timely manner;

- Accessible without unjustified expense or delay by the stakeholders;

- Comprehensive and meaningful so as to enable stakeholders to structure a well-formed view of the insurer;

- Consistent as a useful framework upon which to make decisions; and

- Comparable among different insurance firms.

Because insurance companies are mainly in the risk business (IRDA, 2009), an insurer should identify, understand, and manage the significant risks that it faces through effective and prudent risk management systems, implemented appropriately according to the complexity, size and nature of the insurer's business on an on-going basis in order to indicate potential risks as early as possible. This may include looking at risks by territory or by line of business. Some risks are specific to the insurance sector, like: underwriting risks and risks related to the evaluation of technical provisions. Other risks are similar to those of other financial institutions, such as: market (including interest rate), operational, legal, and organisational risks (IAIS, 2004).

By implementing the appropriate corporate governance strategies effectively and efficiently, the insurer would guarantee stakeholders' confidence and trust in the company's operations and market discipline. The IRDA (2009) listed the key stakeholders in case of an insurer, which include shareholders, policyholders, supervisors and employees. Other stakeholders could include unions, service providers, creditors, equity analysts, rating agencies and the community at large.

The stakeholders are interested in the operations of the insurers in terms of: 
- Its profitability and its capacity to provide a return on capital to shareholders, hire employees, its capability to expand its operations and contribute to economic and social activities; and

- Its ability to meet its obligations to the different stakeholders as they come due, thus also promoting trust and confidence in the financial system.

\section{Methodology : Population and Sampling}

\subsection{Data Collection}

Different sources have been used to collect data for this study. First, several academic journals and articles have been read to have a better understanding of this topic. These previous academic studies have been downloaded online from various websites. Real-time numerical data about the insurance sector and companies have been gathered from Bahrain Stock Exchange and the annual reports of each insurance company which are submitted on their official websites.

\subsection{Data Selection}

Online resources have been utilized for their easy access and information density. They provide available ready-to-use data and massive previous researches. Official annual reports have been employed for their accuracy and consistency.

\subsection{Sample}

The sample is measured to be $100 \%$ of insurance companies listed on Bahrain Stock Exchange, which constitute the whole population. The total observations are 30 for five insurance firms during six consecutive years (2005-2010).

\subsection{Research Methodology}

The method applied to conduct the research is called Pooled Least Squares and the software employed is E-views. It provides various statistics such as coefficient, standard deviation, t-statistic, f-statistic, probability, the mean, median, the maximum value and the minimum value.

\subsection{Study Model}

The figure below is the study model used to examine the effect of corporate governance on the firm's performance. 
Independent Variables

1. Board size.

2. CEO status.

3. Ownership concentration.

4. Firm size.

5. Industry performance.

6. Employees.

7. Shares traded.

ROE

Source: the researcher

\subsection{Model Specification}

This economic model is used to examine the relationship between corporate governance and firm's performance.

$\mathbf{R O E}_{\mathrm{i}, \mathrm{t}}=\beta_{0}+$ Board Size $_{\mathrm{i}, \mathrm{t}} \beta_{1}+$ CEO Status $\mathrm{i}, \mathrm{t} \beta_{2}+$ Ownership concentration $_{\mathrm{i}, \mathrm{t}} \beta_{3}+$ Firm

Size $_{\mathrm{i}, \mathrm{t}} \beta_{4}+\quad$ Industry Performance ${ }_{\mathrm{i}, \mathrm{t}} \beta_{5}+$ Employees $_{\mathrm{i}, \mathrm{t}} \beta_{6}+$ Shared

$\operatorname{Traded}_{\mathrm{i}, \mathrm{t}} \beta_{7}+$ Blockholders $_{\mathrm{i}, \mathrm{t}} \beta_{8}+\mathrm{e}_{\mathrm{i}, \mathrm{t}}$

\subsection{Variables Definition}

\subsubsection{Dependent Variable ROE:}

The amount of net income returned as a percentage of shareholders equity. Return on equity measures a corporation's profitability by revealing how much profit a company generates with the money shareholders have invested. Each insurance firm's ROE has been obtained for its annual reports.

ROE is expressed as a percentage and calculated as: Net Income/Shareholder's Equity * 100 Net income is for the full fiscal year, before any dividends are paid to common stockholders but after dividends are paid to preferred stock. Shareholder's equity does not include preferred shares. 


\subsubsection{Independent Variables}

1. Board size:

This variable determines the number of directors in a board. It's believed that to restore investor confidence in any firm, the board should increase its independence and competence. Empirical studies, however have not found a statistically significant positive relationship between the degree of board independence and better financial performance.

\section{CEO status:}

Several studies have examined the separation of CEO and chairman of the board, positing that agency problems are higher when the same person occupies the two positions. Yermack (1996) shows that firms are more valuable when the CEO and the chairman of the board positions are occupied by different persons. However, Liang and Li (1999) do not find a positive relation on the separation of the position of CEO and board chair.

3. Ownership concentration:

Concentration is measured as a percentage of shares owned by the largest investor. As it's anticipated by (Bolbol, et al, 2003) that that ownership will be less concentrated in economies that are freer, because these economies create conditions which are more likely to encourage participation in firm ownership.

4. Firm size:

In this study, firm size is measured by the total assets in the insurance company. The bigger the firm is the higher risk it faces, thus, more corporate governance mechanisms should be implemented in order to provide higher investor protection.

5. Industry performance:

The industry index provided on BSE presents vital facts about any industry performance in Bahrain. This factor is used to measure the overall performance of the insurance industry on the performance of a specific firm.

6. Employees:

This variable measures the number of employees working in the firm, both local and non-local. In the recent past, companies learned they could create better products more efficiently with the full mental participation of their employees.

7. Shared traded:

The number of shares traded annually should be considered to identify the market movements and the demand for company's shares. Recent trends indicate that the key institutional investors are shifting from trading to owning.

8. Blockholders:

This factor quantifies the number of shareholders who own shares in the company. Shareholders play a major role in the decision process of a company, especially if they have voting rights. Good corporate governors view shareholders as not just suppliers of fund, but also ideas and direction. They are like a monitoring agency and therefore they should participate and perform in company meetings. 


\section{Macrothink

\section{Results}

\subsection{Regression Analysis}

E-views program has been used to calculate the regression and the method is Pooled Least Square. The included observations are 5 insurance companies for the years 2005-2010. Therefore, the total panel of observations is 30 . The economic model used to examine the relationship between corporate governance and firm's performance is:

ROE $_{\mathrm{i}, \mathrm{t}}=\beta_{0}+$ Board Size $_{\mathrm{i}, \mathrm{t}} \beta_{1}+$ CEO Status $_{\mathrm{i}, \mathrm{t}} \beta_{2}+$ Ownership concentration $_{\mathrm{i}, \mathrm{t}} \beta_{3}+$ Firm

Size $_{\mathrm{i}, \mathrm{t}} \beta_{4}+$ Industry Performance $\mathrm{i}, \mathrm{t} \beta_{5}+$ Employees $_{\mathrm{i}, \mathrm{t}} \beta_{6}+$ Shared $\operatorname{Traded}_{\mathrm{i}, \mathrm{t}} \beta_{7}+$

Blockholders $_{\mathrm{i}, \mathrm{t}} \beta_{8}+\mathrm{e}_{\mathrm{i}, \mathrm{t}}$

The results are shown below in Table 4.2.

Table 4.2 Regression analysis

\begin{tabular}{|llll|}
\hline Variable & t-Statistic & Prob. \\
\hline BOARD & & 1.9663187 & 0.0432 \\
CEO & -0.072865 & 0.9428 \\
OWNERSHIP & -1.657000 & 0.1170 \\
FIRMSIZE & 1.790073 & 0.0494 \\
PERFORMANCE & -0.417231 & 0.6821 \\
EMPLOYEES & & 0.099205 & 0.9222 \\
TRADED & -0.506883 & 0.6192 \\
BLOCKHOLDERS & & 1.967254 & 0.0467 \\
\hline R-squared & 0.526588 & & \\
F-statistic & 2.224653 & & \\
Prob.(F-statistic) & 0.049546 & & \\
\hline
\end{tabular}

\subsection{Research Hypothesis}

$\mathrm{H}_{0}$ : there is no a significant impact for corporate governance on firm's performance.

$\mathrm{H} 0$ : there is no significant impact for board size on ROE.

$\mathrm{HO}$ : there is no significant impact for CEO status on ROE.

$\mathrm{H}_{0}$ : there is no significant impact for ownership concentration on ROE.

$\mathrm{H}_{0}$ : there is no significant impact for firm size on ROE.

$\mathrm{H}_{0}$ : there is no significant impact for industry performance on ROE.

$\mathrm{H}_{0}$ : there is no significant impact for number of employees on ROE.

$\mathrm{H}_{0}$ : there is no significant impact for number of shares traded on ROE.

$\mathrm{H}_{0}$ : there is no significant impact for number of blockholders on ROE.

The main hypothesis determines whether all the independent variables together, which represent the corporate governance, have effect on the dependent variable which reflects the 
firm's performance. For this general hypothesis, the f-statistic value is used to reject or accept it. On the other hand, the t-statistic is used to accept or reject all other hypothesizes which measure the relationship between each independent variable and the dependent variable separately.

In order to determine whether to reject the null hypothesis or accept it, the following conditions should be applied to the regression results:

- T-statistic > 1.654;

- Prob. <0.05; and

- F-statistic $>1.81$.

If these conditions are achieved, then there is a significant relationship between the independent variable and the dependent variable.

By implementing these conditions on the regression results, we reached the statistical results shown in Table 4.3 below.

Table 4.3 Statistical results

\begin{tabular}{|l|l|}
\hline Null hypothesis & Reject/Accept \\
\hline $\begin{array}{l}\mathrm{H}_{0}: \text { there is no significant impact for corporate } \\
\text { governance on firm's performance. }\end{array}$ & Reject \\
\hline $\begin{array}{l}\mathrm{H}_{0}: \text { there is no a significant impact for board size } \\
\text { and ROE. }\end{array}$ & Reject \\
\hline $\begin{array}{l}\mathrm{H}_{0}: \text { there is no a significant impact for CEO status } \\
\text { on ROE. }\end{array}$ & Accept \\
\hline $\begin{array}{l}\mathrm{H}_{0}: \text { there is no a significant impact for ownership } \\
\text { concentration on ROE. }\end{array}$ & Accept \\
\hline $\begin{array}{l}\mathrm{H}_{0}: \text { there is no a significant impact for firm size on } \\
\mathrm{ROE} .\end{array}$ & Reject \\
\hline $\begin{array}{l}\mathrm{H}_{0}: \text { there is no a significant impact for industry } \\
\text { performance on ROE. }\end{array}$ & Accept \\
\hline $\begin{array}{l}\mathrm{H}_{0}: \text { there is no a significant impact for number of } \\
\text { employees on ROE. }\end{array}$ & Accept \\
\hline $\begin{array}{l}\mathrm{H}_{0}: \text { there is no a significant impact for number of } \\
\text { shares traded on ROE. }\end{array}$ & Accept \\
\hline $\begin{array}{l}\mathrm{H}_{7}: \text { there is no a significant impact for number of } \\
\text { blockholders on ROE. }\end{array}$ & Reject \\
\hline
\end{tabular}

\section{Discussion}

\subsection{Board Size and ROE}

$\mathrm{H}_{0}$ : there is no a significant impact of board size on ROE.

For the first null hypothesis, the t-statistic is 1.966387 , which is more than 1.654 . The probability is 0.0432 which is less than 0.05 . So this null hypothesis has been rejected as the regression results showed an impact of board size on ROE. Kajola (2008) finds a positive and significant relationship between these two variables. 


\subsection{CEO Status and ROE}

$\mathrm{H}_{0}$ : there is no a significant impact for CEO status on ROE.

Our results together with other researches don't show a significant impact on ROE, as the t-statistic is less than 1.654 and the probability is greater than 0.05 . Therefore, the null hypothesis has been accepted, suggesting that firm performance is not affected by the separation or unification of the CEO and chairperson positions (Bolbol, et al, 2003).

\subsection{Ownership Concentration and ROE}

$\mathrm{H}_{0}$ : there is no a significant impact for ownership concentration on ROE.

Based on the regression results, both conditions don't exist as the t-statistic is less than 1.654 and the probability is greater than 0.05. Thus, there is no significant impact on ROE. This result is consistent with the results of other researchers such as (Bolbol, et al, 2003).

\subsection{Firm Size and ROE}

$\mathrm{H}_{0}$ : there is no a significant impact for firm size on ROE.

The t-statistic value for this variable is 1.790073 , which is greater than 1.654 , and the probability is 0.0494 , which is less than 0.05 . This means that firm size does affect firm's performance as indicated by Table 4.2. This is consistent with the findings of other studies that find large-size firms are more likely to achieve better performance as indicated by the positive and significant relationship (Bolbol, et al, 2003).

\subsection{Industry Performance and ROE}

$\mathrm{H}_{0}$ : there is no a significant impact for industry performance on ROE.

The null hypothesis above has been accepted because as we have found that the conditions don't apply to the t-statistic and the probability so there is no significant relationship between industry performance and ROE. As stated by (Coles, et al, 2001) the lack of any significant relationship between these two variables might be on the short-term only, as the dependent variable used is measured annually. This, however, doesn't undermine in any way the effectiveness of ROE as a performance measure. In fact, the lack of such a relationship may constitute evidence of the effectiveness of proper governance structures in inducing management to undertake long-term value-enhancing projects not necessarily reflected in ROE numbers.

\subsection{Number of Employees and ROE}

$\mathrm{H}_{0}$ : there is no a significant impact for number of employees on ROE.

The t-statistic is 0.099205 and the probability is 0.9222 . Both of them don't apply to the conditions, hence this null hypothesis has been accepted because number of employees is not related to the firm's performance. Tzafrir (2005) argues that employees' participation is what matters more that their number. Because when employees involve in the decision-making process, mistakes will inevitably incur. By increasing the employees' freedom of actions, managers extend their dependency on their employees as well as increasing the level of risk.

\subsection{Number of Shares Traded and ROE}

$\mathrm{H}_{0}$ : there is no a significant impact for number of shares traded on ROE.

Results indicate that there is no significant relationship between the number of shares traded and ROE as the t-statistic is less than 1.654 and the probability is greater than 0.05 . Not many previous researches have studied this independent factor. However, (Talebnia, et al, 2010) 
find that there is a significant relationship between performance and ownership structure generally, regardless to the number of shares traded.

\subsection{Number of Blockholders and ROE}

$\mathrm{H}_{0}$ : there is no a significant impact for number of blockholders on ROE.

According to the regression results, the number of blockholders doesn't affect the firm's performance. However, previous studies found that large blockholders can have an important role in firm governance. It is presumed that blockholders, some of which may be activist institutional investors, have the capability to monitor their investments and, by virtue of the magnitude of their investments, can affect managerial behavior.

The threat that blockholders will sell large blocks of shares if the firm fails to provide an acceptable return, or is not responsive to governance issues that investors view as critical, is becoming a more significant factor for top managers. There is evidence in the empirical literature that institutional investors and other blockholders do impact managerial behavior (e.g., Brickley, Lease and Smith, 1988 and 1994; and Van Nuys, 1993).

5.9 Corporate Governance and Firm's Performance

$\mathrm{H}_{0}$ : there is no significant impact for corporate governance on firm's performance.

The last null hypothesis combines all the independent variables together and their effect on firm's performance. The f-statistic value equals to 2.224653 , which is greater than 1.81 . The second condition, the probability is 0.049546 , which is less than 0.05 . Hence, the null hypothesis has been rejected since the regression results show a significant impact for the corporate governance on firm's performance.

However, Javid, A. \& Iqbal, R. (2006) argue that adequate firm-level governance standards cannot replace the solidity of the firm because the low production and bad management practices cannot be covered with transparent disclosures and transparency standards.

\section{Conclusions}

There is no doubt that several studies have been conducted so far, and still on-going, on the examination of the relationship between firm performance measures and corporate governance mechanisms, but the outcomes of these studies are mixed. They seem to depend quite heavily on the kind of methodology that is used, including how the measurement is defined and the time horizon over which it is measured (Coles, et al, 2001).

In this research, we have begun by studying Bahrain's economy generally and the insurance sector specifically. Then, we have started discussing the several factors that reflect the corporate governance, and how these factors can affect the firm's performance represented by ROE. Five insurance firms have been chosen which are listed on Bahrain Stock Exchange. The numerical data have been captured for six years (2005-2010), from the annual reports submitted by each firm on its official website.

The study model along with the economic model used to examine the impact of corporate governance on firm's performance are included. E-views program has been employed to analyze the data, under Pooled Least Square method. The regression and statistical results are presented. 


\section{Macrothink

We conclude that there is a significant impact for corporate governance on firm's performance in the insurance industry in Bahrain. This result, however, stresses the importance of good governance structure on the firm and the whole economy in the long run.

\subsection{Recommendations}

1- The researcher suggests that every insurance firm should properly define corporate governance and its mechanisms and implement them effectively in order to reach the firm's long-term goals, build stakeholders' confidence and generate positive investment flows.

2- The recent financial crisis has had enormous impacts on the economy, leading to major problems in insurance companies. Therefore, an insurance company should focus on good corporate governance that will build a stable foundation for recovering from this crisis.

3- Regarding future line of research, efforts should be put at increasing the sample size, the corporate governance variables, and the time frame in order to have more accurate and reliable results.

4- More importantly, the empirical literature indicates a sample selection bias in favor of very big firms. It is hereby suggested that attention should be devoted to the study of small- and medium-scale firms. This is because these firms account for at least $90 \%$ of the total number of firms in the world. 


\section{References:}

1. Bolbol, A., Fatherldin, A. \& Omran, M. (2003). Ownership Structure, Firm Performance, and Corporate Governance: Evidence from Selected Arab Countries.

2. Brickley, J. A., Lease, R. C., \& Smith, C. W. (1988). Ownership Structure And Voting On Antitakeover Amendments. Journal of Financial Economics, 20, 267-291.

3. Brickley, J. A., Lease, R. C., \& Smith, C. W. (1994). Corporate Voting: Evidence From Charter Amendment Proposals. Journal of Corporate Finance, 1, 5-31.

4. Coles, J., McWilliams,V. \& Sen, N. (2001). an Examination of the Relationship of Governance Mechanisms on Performance. Journal of Management 27, pp 23-50.

5. English, T., Stading, D., Roth, S. \& Krus, C. (2005). Corporate Governance Best Practices For Insurance Companies: The Current Perspective. Sutherland Asbill \& Brennan LLP.

6. Gollier, C. (2003). To Insure or Not to Insure? An Insurance Puzzle. The Geneva Papers on Risk and Insurance Theory. March.

7. IAIS (2004). Insurance Core Principle on Corporate Governance. Switzerland.

8. IRDA (2009). Corporate Governance Guidelines For Insurance Companies. India.

9. Javid, A. \& Iqbal, R. (2006). Relationships Between Corporate Governance Indicators And Firm Performance In Case Of Karachi Stock Exchange.

10. Kajola, O. (2008). Corporate Governance and Firm Performance: the Case of the Nigerian Listed Firms. EuroJouranls, Inc. 14.

11. La Porta, R., Lopez-de-Silanes, F., Shleifer, A. \& Vishny, R. (2000) Investor Protection and Corporate Governance. Journal of Financial Economies 58, 3-27.

12. Liang, N. \& Li J. (1999). Board Structure and Firm Performance: New Evidence from China's Private Firms. Academy of Management Annual Conference, 7-10 August. Chicago.

13. Mustafa, M., Osmani, S., Elmazi, S., Tosuni, G. \& Aliu, F. (2009). Improving Corporate Governance And Transparency In Banks And Insurance Companies In Kosovo. Reinvest. April.

14. Sapovadia, V. (2009) Good Corporate Governance: An Instrument For Wealth Maximization.

15. Talebnia, G., Salehi, M., Valipour, H. \& Shafiee, S. (2010). Empirical Study of the Relationship between Ownership Structure and Firm Performance: Some Evidence of Listed Companies in Tehran Stock Exchange. Journal of Sustainable Development, Vol 3, No 2

16. Tzafrir, S. (2005). A Universalistic Perspective For Explaining The Relationship Between HRM Practices And Firm Performance At Different Points In Time. Journal of Managerial Psychology, Vol. 21 Iss: 2, 109 - 130.

17. Van Nuys, K. (1993). Corporate Governance Through The Proxy Process: Evidence From The 1989 Honeywell Proxy Solicitation. Journal of Financial Economics, 34, 101-132.

18. Yermack, D (1996). Higher Market Valuation Of Companies With A Small Board Of Directors. Journal of Financial Economics, Vol 40, 185- 211. 
19. Young, B. (2003). Corporate Governance and Firm Performance: Is there a relationship? Ivey Business Journals. September-October. 